\title{
GERODIETETIC BAKERY PRODUCTS ENRICHED WITH VITAMIN D
}

\author{
O. Bortnichuk, O. Bilyk, V. Dozenko, V. Kovbasa \\ National University of Food Technologies
}

\begin{tabular}{l}
\multicolumn{1}{c}{ Key words: } \\
Fortification \\
Vitamin D3 \\
Dry whey \\
Wheat brans \\
Phosphate concentrate \\
Staling \\
\hline \multicolumn{1}{c}{ Article history: } \\
Received 08.11.2018 \\
Received in revised form \\
20.11.2018 \\
Accepted 03.12.2018 \\
\hline
\end{tabular}

Corresponding author:

O. Bortnichuk

E-mail:

npnuht@ukr.net

\begin{abstract}
The technological aspects of production of gerodietetic bakery products are given in the paper. For enrichment of bakery products with physiologically-functional ingredients and expansion of assortment of gerodietetic bakery products dry whey, wheat brans, $\beta$-galactosidase, vitamin D3 are proposed to use. To decrease negative influence on the quality of bakery products of the addition of wheat brans and dry whey phosphate concentrate and $\beta$-galactosidase are proposed to use. It is recommended to use vitamin D3 in bakery products for better assimilation of calcium.

It is installed that the optimal way of making dough is using dispersed phase, in which dry whey, phosphate concentrate, vegetable oil, $\beta$-galactosidase, vitamin D3, wheat brans are dispersed throughout $4 \ldots 7$ minute with speed rotation of the body with gradual increase in speed for 0.7 to $2.3 \mathrm{~s}^{-1}$, and then dough is mixed on dispersed phase with the addition of flour and the rest of the ingredients of the formulation. Experimental results installed optimal wetness to be $44.0 \%$. It is installed that designed bread "Grandmother's" has better organoleptic characteristics because of adding to the recipe investigated raw material and enhancers to improve the taste properties and aroma of finished products. Finished products keep freshness better han wheat bread: after 48 hours of storage the content of more firmly "bound" wetness in this sample was larger by $44.8 \%$ than in the control. It is also installed that the total deformation of crumb in samples with investigated raw materials and enhancers after baking and storage was higher. Developed products can be attributed to products with health properties because they cover day's necessity of organism in physiological-functional ingredients by $25 \%$ or more.
\end{abstract}

DOI: $10.24263 / 2225-2924-2018-24-6-24$ 


\title{
ХЛІБОБУЛОЧНІ ВИРОБИ ГЕРОДІЕТИЧНОГО ПРИЗНАЧЕННЯ, ЗБАГАЧЕНI ВІТАМІНОМ D
}

\author{
О.В. Бортнічук, О.А. Білик, В.Ф. Доценко, В.М. Ковбаса \\ Національний університет харчових технологій
}

У статті розглянуто технологічні аспекти виробництва хлібобулочних виробів геродієтичного призначення. Для збагачення хлібобулочних виробів фізіологічно-функціональними інгредієнтами та розширення асортименту хлібобулочних виробів геродієтичного призначення запропоновано використовувати суху молочну сироватку, пшеничні висівки, $\beta$-галактозидазу, вітамін $D_{3}$. Для нівелювання негативного виливу на якість хлібобулочних виробів сумісного внесення пшеничних висівок та сухої молочної сироватки рекомендовано використовувати фосфатидний концентрат та $\beta$-галактозидазу. Для кращого засвоювання кальйю рекомендовано використовувати в хлібобулочних виробах вітамін $D_{3}$.

Встановлено, що оптимальним способом замімування тіста є використання диспергованої фази, за якої суха молочна сироватка, фосфатидний кониентрат, рослинна олія, $\beta$-галактозидаза, вітамін $D_{3}$, пшеничні висівки диспергуються протягом 4...7 хв зі швидкістю обертання робочого органу з поступовим підвищенням швидкості з 0,7 до 2,3 $\mathrm{c}^{-1}$. Після чого на диспергованій суміші замішується тісто з додаванням борошна і решти компонентів рецептури. Експериментальними дослідженнями визначено оптимальну вологість тіста 44,0\%. Встановлено, щзо розроблений хліб «Бабусин» має кращі органолептичні показники за рахунок внесення до рецептури досліджуваної сировини та поліпшувачів, які покращуюють смакові властивості та аромат готових виробів. Готові вироби зберігають свіжість краще, ніж хліб пшеничний. Так, через 48 год зберігання вміст більш міџно «зв'язаної» вологи у цьому зразку був більшим на 44,8 \%, якщо порівняти з контролем. Загальна деформачія м'якушки зразків із досліджуваною сировиною та поліпшувачами після випікання та зберігання вища. Розроблені вироби можуть бути віднесені до виробів з оздоровчими властивостями, оскільки покривають добову потребу організму в фізіологічно-функиіональних інгредієнтах на $25 \%$ і більше.

Ключові слова: фортифікація, вітамін $D_{3}$, суха молочна сироватка, пшеничні висівки, фосфатидний конщентрат, черствіння.

Постановка проблеми. Для забезпечення організму поживними речовинами, здійснення профілактики та лікування захворювань необхідно харчові продукти, які збалансовані за життєво необхідними інгредієнтами, зокрема амінокислотним складом білків, вмістом харчових волокон, вітамінів і мінеральних речовин. Хліб у харчуванні людей похилого віку є складовою щоденного харчування. Дієтологами рекомендується для людей похилого віку споживати хлібобулочні вироби вчорашньої випічки. Тому підвищення харчової цінності та подовження тривалості зберігання хліба за рахунок використання 
вторинних продуктів переробки зернової та молочної сировини, вітамінів $\epsilon$ пріоритетним напрямом у вирішенні проблеми харчування людей похилого віку.

Процес черствіння знижує споживчі властивості хліба, зокрема органолептичні. Найбільш характерними ознаками черствіння є зміна аромату й смаку, підвищення жорсткості та зниження пружності як скоринки i м'якушки окремо, так і цілого виробу. Подовження термінів свіжості випеченого хліба $\epsilon$ актуальним завданням науковців для надання рекомендацій виробникам хлібобулочних виробів. У зв'язку з цим актуальним є розроблення технології хліба геродієтичного призначення з подовженим терміном зберігання. Дослідження здійснювалася відповідно до тематики науково-дослідної роботи «Наукові засади розроблення інноваційних технологій хлібобулочних виробів підвищеної харчової цінності та термінів їх зберігання» (державний реєстраційний номер 0116U001529).

Аналіз останніх досліджень і публікацій. Хлібобулочні вироби як продукти масового споживання найбільш доступні для корекції харчової та біологічної цінності раціону людини. Незважаючи на досить широкий вітчизняний асортимент, частка виробів оздоровчого призначення в загальному об'ємі виробництва не перевищує $1 . . .2 \%[1-3]$.

Хлібобулочні вироби виробляються, зазвичай, із борошна вищих сортів, тому вони мають досить високу енергетичну цінність, адже борошно на $70 \%$ складається із вуглеводів, які легко засвоюються. Білкові речовини хліба складають лише 6,5...11\%. Вони представлені власне білками, а також продуктами їх гідролізу - пептидами, поліпептидами, амідами та амінокислотами, серед яких присутні всі вісім незамінних. Проте кількість триптофану, лізину та метіоніну досить низька і є лімітованою [4-7].

Відомо, що співвідношення білків і вуглеводів складає 1:7, що не відповідає формулі раціонального харчування. Також хлібобулочні вироби у своєму складі містять невелику кількість вітамінів, мінеральних речовин і харчових волокон, тому вони є продуктами, які необхідно збагачувати біологічно активними речовинами за рахунок нетрадиційних видів сировини. Це дасть змогу також розширити асортимент виробів, надати їм різноманітності за смаковими ознаками.

Світові тенденції зниження калорійності раціону харчування зумовлюють необхідність розширення асортименту продуктів харчування, зокрема хлібопекарських виробів, які б характеризувались підвищеним вмістом харчових волокон. Основною сировиною-джерелом харчових волокон у хлібопекарській промисловості $€$ вторинні продукти переробки борошномельного виробництва - пшеничні висівки.

Науковцями доведено, що пшеничні висівки є джерелами харчових волокон, які містять (\%): білки $-16 \ldots 18 \%$, крохмаль $-14 \ldots 26 \%$, клітковину $5 \ldots 30 \%$, мінеральні речовини $-2 \ldots 7 \%$ та вітаміни (мг \%): $\mathrm{PP}-9 \ldots 14, \mathrm{~B}_{1}-$ $1,0 \ldots 1,2, \mathrm{E}-21 \ldots 33$. Їхні білки більш цінні, якщо порівняти 3 білками пшеничного борошна, за амінокислотним складом [8; 9].

Пшеничні висівки мають понижену калорійність, є регуляторами обміну речовин в організмі людини, завдяки «перистальтичній» дії покращують роботу шлунково-кишкового тракту, сприяють виведенню з організму нещіль- 
ного холестерину, продуктів розкладу, знижують рівень глюкози в крові, сприяють розвитку корисних бактерій та бактеріальному синтезу вітамінів групи В і РР, створюють відчуття насичення, запобігаючи зловживанню висококалорійною їжею, знижують енергетичну цінність продукту, мають протизапальні, послаблюючі та загальнозміцнюючі властивості [10].

Підвищення харчової та біологічної цінності хлібобулочних виробів можна здійснювати за рахунок збільшення в них білка, забезпечення збалансованого амінокислотного складу та внесенням до рецептури виробів харчових волокон.

Один із напрямів покращення біологічної цінності хлібобулочних виробів є залучення до технології продуктів переробки молока. До їх складу входять високоефективні білкові речовини, збалансовані за лізином, триптофаном i метіоніном, добре засвоюваний організмом кальцій, вітаміни групи В та РP, а також молочний цукор і жир [11; 12]. Молочні білки здатні при розщепленні iз кишківника безпосередньо проникати в кров. Кальцій молока, на відміну від кальцію рослинних продуктів, зв'язаний з білком, а не 3 інозитфосфорною кислотою, тому більшою мірою і за простішим механізмом всмоктується в даному відділі шлункового-кишково тракту [1; 14].

СМС має цілий ряд переваг - транспортабельна, тривалий термін зберігання, легкість у використанні. В сухій молочній сироватці міститься близько $70 \%$ лактози, 14\% білка, до 8\% мінеральних речовин. Порівняно із борошном, молочна сироватка значно багатша на незамінні амінокислоти. Лимонна, щавлева та молочні кислоти, які входять до складу СМС, позитивно впливають на якісні показники хлібобулочних виробів. До складу сироватки кальцію входить у 57 разів більше, ніж до борошна. Суху молочну сироватку можна розглядати як цінний мінеральний збагачувач, вона містить в рази більше калію, магнію, йоду, натрію, ніж хліб. Мінеральний склад харчового раціону при щоденному вживанні хліба з СМС значно покращує добове забезпечення кальцію, магнію та фосфору [12]. Використання СМС в оптимальних кількостях дає змогу інтенсифікувати процес тістоприготування, підвищити біологічну якість хліба.

У $[15 ; 16]$ доведено, що завдяки ферментативному гідролізу лактози можна нівелювати ії негативний вплив на реологічні й мікробіологічні процеси в тісті та якість готових виробів. У результаті ферментної модифікації дисахариду утворюється еквімолярна кількість глюкози та галактози. Глюкоза досить легко асимілюється хлібопекарськими дріжджами, а галактоза бере активну участь реакції Майяра, що надає кінцевому продукту приємного кольору та смаку. Як промислові продуценту $\beta$-галактозидази використовують дріжджі, мікроскопічні гриби і бактерії. Грибна $\beta$-галактозидаза більш стабільна, ніж дріжджова і бактеріальна.

У харчовій промисловості використовують широкий спектр ПАР (фосфатидні концентрати, моно- та дигліцериди жирних кислот, їхні суміші, ефіри поліоксіетиленгліколю, сорбіту, пропіленгліколю, сахарози тощо), що різняться між собою хімічним складом, будовою та характером впливу на компоненти харчових систем, в які їх вносять. Також їх використовують для подовження свіжості хлібобулочних виробів, які вступають у взаємодію з біополімерами 
борошна, утворюючи складні комплексні сполуки, що поліпшують структурномеханічні властивості тіста та якість хлібобулочних виробів [17].

Останнім часом проблеми, пов'язані зі структурно-функціональними порушеннями кісткової тканини у людей старшого віку, набули значної актуальності і все частіше привертають до себе увагу як науковців, так і лікарів [18].

Основним завданням у лікуванні остеопорозу є нормалізація процесів кісткового ремоделювання, насамперед пригніченняя прискореної кісткової резорбції та стимулюванням зниженого кісткоутворення, що приводить до підвищення мінеральної щільності кісткової тканини або принаймні до ії̈ стабілізації та покращення якості кістки, зниження кількості нових травм [19].

Відомо, що проліферація та диференціювання остеобластів, синтез специфічних білків, ферментів, мінеральний обмін кістки регулюються передусім активними метаболітами вітаміну $\mathrm{D}_{3}$. Вони зменшують резорбцію кісткової тканини, сприяють мобілізації Са в кістку [20].

Названі фактори вказують на можливість використання сухої молочної сироватки, пшеничних висівок, фосфатидних концентратів, $\beta$-галактозидази для створення хлібобулочних виробів геродієтичного призначення.

Метою дослідження $\epsilon$ розширення технології хліба геродієтичного призначення шляхом збагачення харчовими волокнами, незамінними амінокислотами, вітамінами 3 урахуванням технологічних властивостей вторинних сировинних ресурсі.

Матеріали і методи. Матеріалом досліджень було обрано пшеничні висівки, суха молочна сироватка, фосфатидний концентрат, $\beta$-галактозидаза нового покоління, вітамін $\mathrm{D}_{3}$, тісто та хліб з пшеничного борошна першого сорту.

Методи досліджень - органолептичні, фізико-хімічні, загальноприйняті та спеціальні, виконані з використанням сучасних приладів та інформаційних технологій.

Викладення основних результатів досліджень. Під час розробки рецептури хліба геродієтичного призначення рекомендовано використовувати суху молочну сироватку ПП «Карпатські зорі», вміст білка в якій складає 15,9\%. Крім того, сироватка багата на кальцій [21]. Як харчові волокна рекомендовано використовувати пшеничні висівки виробництва ВАТ «Агрокапітал України». Ці висівки характеризуються високим вмістом харчових волокон, низьким гранулометричним складом, що забезпечує кращі показники пористості та зовнішнього вигляду готових виробів [22]. Для ферментативного гідролізу сухої молочної сироватки запропоновано використовувати $\beta$-галактозидазу [22]. Із зростанням тенденції до здорового харчування використання фосфатидних концентратів особливо актуальне, оскільки фосфоліпіди $\epsilon$ обов'язковими компонентами клітинних мембран усіх живих організмів, які виконують роль несучих конструкцій і беруть участь у процесах обміну речовин. Рекомендовано в технології хлібобулочних виробів використовувати знежирений соняшниковий фосфатидний концентрат [22]. У людей похилого віку засвоєння кальцію організмом покращується при наявності вітаміну $\mathrm{D}_{3}$, високому вмісті білків та лактози, оптимальному співвідношенні 3 фосфором і магнієм. Проте погіршується його засвоєння при високій 
концентрації калію, магнію і фосфору [22]. Використання фосфатидного концентрату, окрім підвищення якості готового виробу, забезпечує зменшення втрати вітаміну $\mathrm{D}_{3}$ у разі приготування хліба в два рази [22].

У результаті досліджень [22] розроблено рецептуру хліба геродієтичного призначення «Бабусин» (табл. 1).

Таблиия 1. Уніфікована рецептура хліба «Бабусин», кг/100 кг борошна

\begin{tabular}{|c|c|}
\hline Найменування сировини & Витрата сировини, кг \\
\hline Борошно пшеничне першого сорту & 100,0 \\
\hline Дріжджі хлібопекарські пресовані & 3,0 \\
\hline Сіль кухонна харчова & 1,5 \\
\hline Фосфатидний концентрат & 0,7 \\
\hline Рослинна олія & 4,0 \\
\hline Суха молочна сироватка & 5,0 \\
\hline Пшеничні висівки & 10,0 \\
\hline$\beta$-галактозидаза до маси сухої молочної & $1: 3500$ \\
\hline сироватки & 15 мг/100 кг борошна \\
\hline Вітамін $\mathrm{D}_{3}$ &
\end{tabular}

У зв'язку з використанням вітаміну $\mathrm{D}_{3}$ необхідна спеціальна технологічна підготовка інгредієнтів перед їх змішуванням з пшеничним борошном.

Для реалізації технології було запропоновано використовувати дисперговану фазу. Призначення диспергованої фази пов'язано з формуванням технологічних властивостей тіста та якості хліба 3 досліджуваною сировиною, а ії обгрунтованість наведено у вигляді табл. 2 .

Таблиия 2. Призначення диспергованої фази в технології хліба геродістичного призначення

\begin{tabular}{|c|c|c|}
\hline Технологічні операції & $\begin{array}{c}\text { Мета } \\
\text { технологічної операції }\end{array}$ & $\begin{array}{c}\text { Роль у формуванні } \\
\text { властивостей тіста та якості } \\
\text { хлібобулочних виробів }\end{array}$ \\
\hline Використання вітаміну D & \begin{tabular}{|c|} 
Рівномірне розподілення вітаміну \\
в об’ємі розчину, що забезпечує \\
рівномірність розподілу у всьому \\
об'ємі готового виробу \\
\end{tabular} & $\begin{array}{c}\text { Не впливає на властивості } \\
\text { тіста та якість } \\
\text { хлібобулочних виробів }\end{array}$ \\
\hline $\begin{array}{l}\text { Використання рослинної } \\
\text { олії }\end{array}$ & Розчинення вітаміну $\mathrm{D}_{3}$ & Надання тісту еластичності \\
\hline Використання ПАР & \begin{tabular}{|c|} 
Збільшення питомої поверхні \\
взаємодії зі складовими борошна в \\
тістовій системі
\end{tabular} & $\begin{array}{c}\text { Формування пружно- } \\
\text { еластичних властивостей } \\
\text { клейковини і тіста }\end{array}$ \\
\hline $\begin{array}{c}\text { Використання } \\
\beta \text {-галактозидази }\end{array}$ & \begin{tabular}{|c|} 
Piвномірне розподілення ферменту \\
в об’ємі розчину, що покращує \\
процес ферментативної \\
модифікації лактози
\end{tabular} & $\begin{array}{l}\text { Інтенсифікація спиртового } \\
\text { бродіння в тісті }\end{array}$ \\
\hline $\begin{array}{c}\text { Нагрівання води }(t= \\
\left.=40 \ldots 45^{\circ} \mathrm{C}\right) \text {, призначеної } \\
\text { для диспергування }\end{array}$ & \multirow{2}{*}{$\begin{array}{l}\text { Отримання рівноважної колоїдної } \\
\text { системи з температурою } 31 \ldots 33^{\circ} \mathrm{C}\end{array}$} & $\begin{array}{c}\text { Інтенсифікація процесу } \\
\text { диспергування }\end{array}$ \\
\hline $\begin{array}{c}\text { Диспергування } \\
\text { інгредієнтів рецептури }\end{array}$ & & $\begin{array}{l}\text { Рівномірний розподіл } \\
\text { компонентів }\end{array}$ \\
\hline
\end{tabular}


Особливостями технологічного процесу виробництва хліба на диспергованій фазі запропонована подовжена механічна обробка тіста тривалістю 15 хв. Диспергована фаза складається із суміші води температурою $45 \ldots 50^{\circ} \mathrm{C}$ в кількості $65 \ldots 85 \%$ від загальної розрахункової кількості, сухої молочної сироватки в кількості 5\% до маси борошна, фосфатидного концентрату в кількості $0,7 \%$ до маси борошна, рослинної олії в кількості 4,5\% до маси борошна, $\beta$-галактозидази у співвідношенні до лактози СМC як 1:3500, вітаміну $\mathrm{D}_{3}$ у кількості $0,015 \%$ до маси борошна 3 додатковим внесенням пшеничних висівок у кількості 10\% до маси борошна.

Подальші дослідження стосувалися визначення вологості тіста, як важливого параметра тістоприготування. Від їі величини залежить інтенсивність фізико-хімічних, біохімічних, мікробіологічних і колоїдних процесів, консистенція тістових напівфабрикатів і вологість хліба.

Для встановлення оптимальної вологості готували зразки тіста з масовою часткою вологи 43,$0 ; 44,0$ та 45,0\%. Тісто готували за рецептурою, наведеною в табл. 1. Визначали вплив масової частки вологи на технологічний процес $\mathrm{i}$ якість виробів. Результати досліджень наведені в табл. 3.

Таблиия 3. Вплив вологості тіста на показники технологічного процесу та якість готових виробів

\begin{tabular}{|c|c|c|c|}
\hline Показники якості & \multicolumn{3}{|c|}{ Тісто } \\
\hline Масова частка вологи, \% & 43 & 44 & 45 \\
\hline Тривалість бродіння, хв & \multicolumn{3}{|c|}{180} \\
\hline Газоутворення, см ${ }^{3} / 100$ г & 563 & 565 & 556 \\
\hline Розпливання, \% & 185 & 191 & 198 \\
\hline Консистенція & \multicolumn{2}{|c|}{$\begin{array}{c}\text { Сухе на дотик, добре } \\
\text { формується }\end{array}$} & $\begin{array}{c}\text { 3'являється липкість, } \\
\text { погано формується }\end{array}$ \\
\hline & \multicolumn{3}{|c|}{ Хліб } \\
\hline Питомий об'єм, см ${ }^{3} / 100 г$ & 323 & 331 & 315 \\
\hline Формостійкість, Н/D & 0,39 & 0,38 & 0,35 \\
\hline Пористість, \% & 70 & 71 & 68 \\
\hline Кислотність, град & 2,4 & 2,3 & 2,2 \\
\hline Характеристика м'якушки & $\begin{array}{c}\text { Еластична, 3 добре розвиненою } \\
\text { пористістю, рівномірна }\end{array}$ & $\begin{array}{c}\text { Еластична, крупна, } \\
\text { нерівномірна }\end{array}$ \\
\hline
\end{tabular}

Встановлено, що зі збільшенням вологості тіста в'язкість тіста зменшується, про це свідчить збільшення його розпливання на 3,3 та 7,7\% відповідно. На сумарне газоутворення підвищення вологи практично не впливає.

За масової частки вологи $43,0 \%$ i 44,0\% тісто було сухе на дотик, добре формувалось. За вологості 45,0\% - ставало вологим на дотик, з'явилась липкість, ускладнювалось формування, погіршувалась формостійкість виробів на $10,3 \%$, якщо порівняти із зразком тіста вологістю $43,0 \%$. Кращі показники якості за об'ємом, пористістю, станом м'якушки, характером іiї пор були у хліба в разі приготування тіста з масовою часткою вологи $44,0 \%$.

У технології хліба тісто здебільшого готують опарним або безопарним способом, залежно від виду виробів, їх рецептурного складу. Кожен з них має свої переваги та недоліки. 
За безопарного способу тривалість технологічного процесу майже вдвічі менша, ніж за опарного, необхідно менше технологічного обладнання, але якість виробів дещо нижча за станом м'якушки, смаковими характеристиками.

Опарний спосіб, порівняно 3 однофазним, більш гнучкий, має менші витрати дріжджів для приготування тіста. Хліб за цього способу кращий на смак і аромат, довше зберігає свіжість. Проте за опарного способу досить тривалий технологічний процес $(4,5 \ldots .5$ год).

За вибору способу приготування тіста, особливо при використанні нетрадиційної сировини, яка має відмінні від борошна хімічний склад і технологічні властивості, основним критерієм має бути забезпечення високих показників якості хлібобулочних виробів.

Під час проведення досліджень тісто готували трьома різними способами:

1. Безопарним - всі складові рецептури вносили безпосередньо до борошна і проводили заміс тіста. Тривалість замішування протягом 15 хв 3 масовою часткою вологи 44\%. При зазначеному способі вносили $3 \%$ пресованих дріжджів.

2. На традиційній густій опарі - опару готували вологістю $47 \% 3$ використанням половини борошна, внесенням всієї кількості ПВ, СМС, лецетину та ферменту $\beta$-галактозидази. В опару вносили $1 \%$ пресованих дріжджів. Тривалість іiі бродіння була 3,5 год при $28 \ldots 32^{\circ} \mathrm{C}$. Тісто з масовою часткою вологи $44 \%$ замішували протягом 15 хв, тривалість бродіння тіста на опарі була $75 \ldots 80$ хв.

3. На диспергованій фазі, рецептура якої наведена вище, компоненти суміші диспергуються протягом $4 . .7$ хв зі швидкістю обертання робочого органа 3 поступовим підвищенням швидкості з 0,7 до $2,3 \mathrm{c}^{-1}$ i, після чого на диспергованій суміші замішується тісто $з$ додаванням борошна і решти компонентів рецептури.

Як показали результати досліджень (табл. 4), кращі показники якості виробів були зафіксовані при приготуванні тіста на диспергованій фазі.

Таблиця 4. Вплив способу приготування тіста 3 композиційною сумішшю на якість хліба

\begin{tabular}{|c|c|c|c|}
\hline \multirow{2}{*}{ Показник } & \multicolumn{3}{|c|}{ Спосіб приготування тіста } \\
\cline { 2 - 4 } & Безопарний & $\begin{array}{c}\text { На диспергованій } \\
\text { фазі }\end{array}$ & $\begin{array}{c}\text { На традиційній } \\
\text { густій опарі }\end{array}$ \\
\hline \multicolumn{3}{|c|}{ Хліб } \\
\hline Питомий об'єм, см ${ }^{3} / 100$ г & 280 & 331 & 288 \\
\hline Кислотність, град. & 2,2 & 2,2 & 2,2 \\
\hline Пористість, \% & 68 & 74 & 70 \\
\hline Формостійкість, Н/D & 0,39 & 0,42 & 0,40 \\
\hline Загальна деформація м'якушки, од. пенетрометра: \\
\hline - через 1 добу & 94 & 110 & 96 \\
\hline - через 2 доби & 80 & 92 & 82 \\
\hline Характеристика м'якушки & Менш еластична & Еластична & Еластична \\
\hline
\end{tabular}

Приготовлений на диспергованій фазі хліб мав на $14,9 \ldots 18,2 \%$ більший питомий об'єм порівняно з хлібом, що готувався безопарним та опарним 
способом, мав добре розвинуту, рівномірну пористість, яка також була більшою на $5,7 \ldots 8,8 \%$.

Це можна пояснити тим, що основними технологічними функціями фосфатидних концентратів у хлібопеченні $\epsilon$ емульгування, комплексоутворення 3 крохмалем, взаємодія з білками, зміна в'язкості та модифікація кристалів.

Отже, саме в складі диспергованої фази фосфатидний концентрат може максимально реалізувати свою технологічну роль, яка грунтується на дифільній будові молекули фосфатидного концентрату, тобто містить у своєму складі полярну гідрофільну (негативно заряджений залишок фосфорної кислоти) i катіонна група основи холіну які розміщуютья на протилежних кінцях молекули. Гідрофільна група забезпечує розчинність у воді, а гідрофобна - у жирах.

Завдяки цьому відбувається рівномірне розосередження фосфатидного концентрату у складі диспергованої фази, його взаємодія з білками, складовими крохмалю та пшеничних висівок. Крім того, фосфатидний концентрат диспергує жир на мілкі жирові кульки, що перешкоджає їх злипанню і стабілізує емульсію. В такому стані часточки жиру при замісі тіста краще розосереджуються між рецептурними компонентами, утворюючи тонкі плівки. При бродінні дріжджового тіста ці плівки «обгортають» утворений діоксид вуглецю і перешкоджають його виходу із тіста.

У результаті проведених досліджень установлено, що приготування хліба в рецептуру якого включені пшеничні висівки, суха молочна сироватка, фосфатидний концентрат та рослинна олія на диспергованій фазі забезпечує більш високі показники якості готової продукції, якщо порівняти з безопарним та опарним способами виробництва. При цьому рекомендована частка вологи в тісті має складати $44 \%$.

За цим способом об'єм хліба був більшим на $14,9 \ldots 18,2 \%$, порівняно 3 додаванням сировини безпосередньо в тісто чи в опару, кращою була пористість (на $5,7 . .8,8 \%$ ) і стан м'якушки.

Це можна пояснити тим, що при доданні пшеничних висівок в опару розчинні харчові волокна довше контактують зі складовими борошна, що призводить до погіршення структурно-механічних властивостей тіста. При використанні безопарного способу приготування тіста, очевидно, ПАР не сповна проявляв свої властивості, що негативно впливало на якісні характеристики готових виробів.

Смак і аромат хлібобулочних виробів $є$ одним із основних органолептичних показників саме цього виду продукції у споживачів, тому їх якість і стійкість у процесі зберігання є суттєвою ознакою. Приємний смак і аромат хліба сприяють підвищенню секреції ферментів шлунково-кишкового тракту і цим забезпечують швидше та якісніше засвоювання поживних речовин.

Формування смаку й аромату хліба залежить від хімічного складу його рецептурних компонентів, технології приготування та способу випікання.

Значна частина ароматичних речовин накопичується під час дозрівання тістових напівфабрикатів, що пов'язано з активністю біохімічних і мікробіологічних процесів. Так, на смак і аромат виробів значною мірою впливає вміст органічних кислот, що накопичуються в процесі бродіння тіста, їх склад, співвідношення молочної та оцтової кислот. 
Утворення ароматичних речовин під час випікання залежить від його тривалості й температури, наявності та співвідношення редукувальних цукрів і амінокислот. До ароматичних сполук належать леткі кислоти, спирти, ефіри, альдегіди та кетони, які утворюються під час випікання [23].

Зберігання хліба призводить до зменшення інтенсивності й виразності аромату, оскільки ароматичні речовини із скоринки частково звітрюються, а частково мігрують до м'якушки і з часом адсорбуються на іiі складових, що призводить до втрати виробами аромату. Тому було визначено вміст ароматичних речовин у скоринці і м'якушці дослідних зразків. Визначення проводили за методом Токарєвої та Кретовича, що базується на зв'язуванні карбонільних сполук бісульфітом натрію [24]. Зміну вмісту бісульфітзв'язуючих сполук досліджували через 4 та 48 год після випікання (табл. 5).

Таблиця 5. Вплив досліджуваної сировини та поліпшувачів на утворення бісульфітзв'язуючих речовин

\begin{tabular}{|c|c|c|}
\hline \multirow{2}{*}{$\begin{array}{c}\text { Тривалість } \\
\text { зберігання, год }\end{array}$} & \multicolumn{2}{|c|}{$\begin{array}{l}\text { Вміст бісульфітзв'язуючих речовин у хлібі, } \\
\text { мг-екв./100г }\end{array}$} \\
\hline & контроль & хліб «Бабусин» \\
\hline & \multicolumn{2}{|c|}{ М'якушка } \\
\hline 4 & 5,1 & 6,4 \\
\hline \multirow[t]{2}{*}{48} & 2,6 & 5,5 \\
\hline & \multicolumn{2}{|c|}{ Скоринка } \\
\hline 4 & 11,9 & 15,8 \\
\hline 48 & 7,8 & 9,1 \\
\hline
\end{tabular}

Дослідження показали, що всі зразки мали краще забарвлену скоринку, якщо порівняти з контролем, що свідчить про наявність у їх скоринці більшої кількості бісульфітзв'язуючих речовин. Очевидно, це пов'язано із внесенням до рецептури хліба «Бабусин» додаткової кількості білків, амінокислот, моносахаридів і лактози з сухою молочною сироваткою та пшеничними висівками.

Встановлено, що початковий рівень бісульфітзв'язуючих речовин для дослідних зразків у скоринці був вищий на $25,5 \ldots 33,3 \%$, у м'якушці - на $31,1 \ldots 36,1 \%$ на початку зберігання та у скоринці - на $111 \ldots 127 \%$, у м'якушці - на $16,9 \ldots 29,5 \%$ через 48 год після випікання, якщо порівняти 3 контрольним зразком.

Отримані результати підтверджують, що внесення до рецептури досліджуваної сировини та поліпшувачів покращує смакові властивості й аромат готових виробів.

Процес черствіння хліба є комплексом процесів, які одночасно відбуваються у білкових речовинах, складного перерозподілу вологи в м'якушці і ретроградацією крохмальних зерен. Практично свіжий хліб повинен мати хорошу стисливість усього виробу, м'якість і еластичність м'якушки, приємний смак та аромат.

При зберіганні хлібобулочні вироби втрачають привабливість для споживача - відбувається усихання скоринки і підскоринкових шарів м'якушки. Це 
надає виробам жорсткості. Поряд з усиханням відбувається процес старіння колоїдних систем м'якушки, крохмалю і білків, хлібобулочні вироби черствіють.

Відомо, що при внесенні до рецептури хлібобулочних виробів такої сировини, як пшеничні висівки, які володіють високими вологоутримувальними та водопоглинальними властивостями, та фосфоліпіду, спостерігається сповільнення черствіння готових продуктів.

Під час проведення досліджень визначали структурно-механічні властивості м'якушки за пенетрометром АП-4/I, iї кришкуватість і водопоглинальну здатність, якщо порівняти 3 контрольним зразком хліба, що виготовлявся 3 борошна першого сорту (табл. 6). Визначення проводили після випікання та через 24 і 48 год після випікання.

Таблиия 6. Показники деформації м'якушки хлібобулочних виробів геродієтичного призначення

\begin{tabular}{|c|c|c|}
\hline \multirow{2}{*}{ Показники } & \multicolumn{2}{|c|}{ Деформація м'якушки, од. приладу } \\
\cline { 2 - 3 } & Контроль & Хліб «Бабусин» \\
\hline Після випікання: & 65 & 68 \\
\hline загальна & & 53 \\
\hline Через 24 години: & 48 & 78 \\
\hline загальна & 74 & 38 \\
\hline Ступінь збереження свіжості, \% & & 56 \\
\hline Через 48 годин: & 30 & \\
\hline загальна & 46 & \\
\hline Ступінь збереження свіжості, \% &
\end{tabular}

Встановлено, що загальна деформація м'якушки зразків із досліджуваною сировиною та поліпшувачами після випікання є вищою на 4,6..7,7\%. При зберіганні 24 та 48 год розроблені вироби зберігають кращу свіжість і мають вищі показники деформації м'якушки, якщо порівняти з контролем.

Очевидно, це пов'язано з використанням емульгатора в рецептурі нових виробів. Білки борошна і сухої молочної сироватки, взаємодіючи з ПАР, утворюють комплекси ПАР-білок, які відіграють важливу роль у формуванні і підтримці структурно-механічних властивостей тіста й хліба.

Крім того, завдяки утвореним комплексам діоксин вуглецю затримується у тістовій заготовці, розвиваючи таким чином питомий об'єм готового виробу i пористість м'якушки, що безпосередньо пов'язано з подовженням терміну зберігання свіжості. Сприяють збереженню свіжості хліба також лактоза і продукти іiі гідролізу.

Основну роль у збереженні свіжості хлібобулочних виробів відіграє «зв'язана» волога. Чим більший вміст «зв'язаної» вологи в готовому виробі, тим довший термін його зберігання. В пшеничному борошні вміст «зв'язаної» вологи коливається в межах $30 \ldots 40 \%$. Вся інша волога знаходиться у вільному стані і може брати участь у біохімічних перетворюваннях, які проходять при зберіганні хлібобулочних виробів.

3 табл. 7 видно, що початковий вміст «зв'язаної» вологи для розроблених виробів є вищим на $1,6 \ldots 2,8 \%$, а iї втрати при зберіганні $є$ меншими на $37,9 \ldots 44,8 \%$, якщо порівняти 3 контролем. 
Таблиця 7. Втрати «зв'язаної» вологи у розроблених виробах

\begin{tabular}{|c|c|c|c|c|}
\hline \multirow[t]{2}{*}{ Зразки } & \multirow{2}{*}{$\begin{array}{c}\text { Тривалість } \\
\text { зберігання, год }\end{array}$} & \multicolumn{2}{|c|}{$\begin{array}{c}\text { Масова частка вологи, \% } \\
\text { до загальної кількості }\end{array}$} & \multirow{2}{*}{$\begin{array}{c}\text { Втрати } \\
\text { «зв'язаної»» } \\
\text { вологи, \% }\end{array}$} \\
\hline & & «вільна» & «зв’язана»» & \\
\hline Хліб пшеничний (контроль) & $\begin{array}{l}24 \\
48\end{array}$ & $\begin{array}{l}78,4 \\
840\end{array}$ & $\begin{array}{l}24,0 \\
182\end{array}$ & 5,8 \\
\hline Хліб «Бабусин» & $\begin{array}{l}24 \\
48\end{array}$ & $\begin{array}{l}73,5 \\
76,8\end{array}$ & $\begin{array}{l}26,5 \\
23,2\end{array}$ & 3,3 \\
\hline
\end{tabular}

Так, через 48 год зберігання вміст більш міцно «зв’ язаної» вологи у цьому зразку перевищував контрольні показники на 44,8\%.

Очевидно, це обумовлено вмістом у рецептурі розроблених виробів білків, інших гідрофільних речовин та емульгатора, який частково вступає у взаємодію із білками тіста та крохмалю, утворюючи комплекси, які більш міцно зв'язують вологу. Результати, отримані за допомогою дериватографа, корелюють 3 одержаними на пенетрометрі.

Враховуючи положення наукової гіпотези щодо підвищення харчової та біологічної цінностей хлібобулочних виробів геродієтичного призначення, досліджено вміст основних харчових речовин у розроблених виробах. Як контрольний зразок обрано хліб, виготовлений з борошна першого сорту, як дослідний - хліб «Бабусин»

Таблиия 8. Харчова та енергетична цінності хлібобулочних виробів геродієтичного призначення

\begin{tabular}{|c|c|c|c|c|}
\hline Найменування виробу & Білки, г & Жири, г & Вуглеводи, г & Енергетична цінність, ккал \\
\hline Контроль & 7,2 & 3,6 & 46,1 & 245 \\
\hline Хліб «Бабусин» & 9,7 & 2,4 & 44,8 & 223 \\
\hline
\end{tabular}

Таблиия 9. Забезпечення добової потреби в основних нутріснтах і харчових волокнах при споживанні 277 г хліба «Бабусин», розрахунок проводився для чоловіків, які зайняті легкою працею (II група інтенсивності праці)

\begin{tabular}{|c|c|c|c|c|c|}
\hline \multirow{2}{*}{$\begin{array}{c}\text { Харчові } \\
\text { речовини }\end{array}$} & \multirow{2}{*}{$\begin{array}{c}\text { Середня } \\
\text { добова } \\
\text { потреба }\end{array}$} & \multicolumn{2}{|c|}{ Міститься в 277 г хліба } & \multicolumn{2}{|c|}{ Покриття добової потреби, \% } \\
\hline & & Контроль & $\begin{array}{c}\text { Хліб } \\
\text { «Бабусин» }\end{array}$ & Контроль & $\begin{array}{c}\text { Хліб } \\
\text { «Бабусин» }\end{array}$ \\
\hline Білки, г & 55 & 19,9 & 26,9 & 36,18 & 48,9 \\
\hline Жири,г & 56 & 0,9 & 0,5 & 1,6 & 0,89 \\
\hline Вуглеводи, г & 320 & 75,2 & 61,3 & 23,5 & 19,2 \\
\hline Харчові волокна,г & 25 & 2,5 & 11,5 & 10 & 46,0 \\
\hline \multicolumn{6}{|l|}{ Мінер. речовини, мг: } \\
\hline кальцій & 1100 & 18 & 48 & 1,6 & 4,4 \\
\hline фосфор & 1200 & 87 & 302 & 7,3 & 25,2 \\
\hline магній & 350 & 16 & - & 4,6 & - \\
\hline залізо & 17 & 1,2 & - & 7,1 & - \\
\hline \multicolumn{6}{|l|}{ Вітаміни, мг: } \\
\hline тіамін & 1,3 & 0,17 & 0,51 & 13,0 & 39,2 \\
\hline рибофлавін & 1,6 & 0,08 & 0,18 & 5,0 & 11,6 \\
\hline Вітамін $\mathrm{D}_{3}, \Gamma$ & 0,01 & 0 & 0,025 & 0 & 250 \\
\hline $\begin{array}{c}\text { Енергетична } \\
\text { цінність, кКал }\end{array}$ & 2500 & 678,7 & 617,7 & 27,1 & 24,7 \\
\hline
\end{tabular}


У результаті проведених досліджень підтверджена теорія щодо підвищення харчової й біологічної цінності хлібобулочних виробів з використанням сухої молочної сироватки та пшеничних висівок.

Отже, розроблені вироби можуть бути віднесені до виробів з оздоровчими властивостями, оскільки забезпечують добову потребу організму в фізіологічно-функціональних інгредієнтах на $25 \%$ і більше.

\section{Висновки}

У результаті експериментальних досліджень розроблено рецептуру хліба геродієтичного призначення «Бабусин», у склад якого входять пшеничні висівки, суха молочна сироватка, вітамін $\mathrm{D}_{3}$, фермент $\beta$-галактозидаздазу та фосфатидний концентрат.

Проведені дослідження показали, що оптимальною вологістю тіста $є 44,0 \%$. Пшеничні висівки, суху молочну сироватку, вітамін $\mathrm{D}_{3}$, фермент $\beta$-галактозидаздазу та фосфатидний концентрат слід вносити в тісто у вигляді диспергованої фази, що забезпечує високу якість готових виробів.

Встановлено, що розроблений виріб краще зберігає свіжість, ніж хліб пшеничний, має кращий аромат, що підтверджено збільшенням в цих виробах бісульфітзв'язуючих сполук у скоринці та м'якушці.

Доведено, що хліб «Бабусин» має більш цінний хімічний склад, ніж хліб тільки 3 пшеничного борошна за вмістом білка, харчових волокон, вітамінів, мінеральних речовин.

\section{Лiтература}

1. Васильченко А.Н. Состояние и перспективы развития хлебопекарной промышленности в Украине. Харчова наука і технологія. 2009. № 1. С. 5-8.

2. Арсеньєва Л.Ю. Наукове обгрунтування та розроблення технології функціональних хлібобулочних виробів з рослинними білками та мікронутрієнтами: дис. ... доктора техн. наук: 05.18.01 / Арсеньєва Лариса Юріївна. Київ, 2007. 325 с.

3. Капрельянц Л.В., Іоргачова К.Г. Функціональні продукти: монографія. Одеса: Друк, 2003. $312 \mathrm{c}$.

4. Росляков Ю.Ф., Вершинина О.Л., Гончар В.В. Научные основы разработки хлебобулочных изделий функционального назначения. Кондитерское и хлебопекарное производство. 2009. № 8. С. $34-35$.

5. Сафонова О.М. Наукове обгрунтування та розроблення технологій борошняних кондитерських і хлібопекарських продуктів 3 використанням нетрадиційної борошняної сировини: дис. ... д-ра техн. наук: 05.18.01 / НУХТ. Київ, 2007. 335 с.

6. Designing and implementing health care provider payment systems [Electronic resource]: how-to manuals / ed.: J. C. Langenbrunner, S. O’Dougherty ; ed. C.Cashin. Washington D.C.: The World Bank, 2009. 348 p.

7. Доронин, А. Ф. Функциональное питание / А. Ф. Доронин, Б. А. Шендеров. М. : ГРАНТЬ, 2002. $402 \mathrm{c}$.

8. Арсеньєва Л.Ю., Борисенко О.В., Доценко В.Ф. Теоретичні та практичні аспекти використання тонкодиспергованих концентратів харчових волокон у технології житньопшеничного хліба. Наукові праці Національного університету харчових технологій. 2008. № 25. C. $115-119$.

9. Борисенко О.В. Удосконалення технології хлібобулочних виробів, збагачених харчовими волокнами: дис... канд. тех. наук 05.18.01 / НУХТ. Київ, 2008. 234 с. 
10. Юрчак В.Г. Наукове обгрунтування та розроблення технології макаронних виробів поліпшеної якості та профілактичного призначення шляхом використання нетрадиційної сировини і харчових добавок : дис. ... доктора техн. наук : 05.18.01 / Київ, 2003. 315 с.

11. Буганцов Ю.А. Свойства молочных белков. Мяс. технол. 2009. № 5. С. 34.

12. Буйлова Л.А., Острецова Н.Г. Призводство сухой сыворотки Переработка молока. 2008. № 9. С. $40-41$.

13. Юкало А.В., Сторож Л.А., Юкало В.Г. Протеїни казеїнового комплексу молока корів (Bos taurus) як попередники біологічно активних пептидів. Biotechnologia Acta. 2012. T. 5, № 4. C. 21-33.

14. Разработка технологий молочно-растительных продуктов питания / Т.М. Бойцова, Т.К. Каленик, Д.В. Ряписов и др. Пищевая промыщленность. 2011. № 3. С. 12-14.

15. Ткачук Ю.М. Технологія хлібобулочних виробів, збагачених молочними білками: дис. ...кандидата техн. наук: 05.18.01 / Ткачук Юрій Михайлович. Київ, 2014. 324 с.

16. Савчук Н.І. Удосконалення технології хліба з борошна зі зниженими хлібопекарськими властивостями шляхом використання поліпшувачів: Дис. ...канд. тех. наук: 05.18.01. Київ, 2002. 185 с.

17. Вплив жирових композицій та емульгаторів на поліпшення споживчих властивостей хліба. Хлібопекарська і кондитерська промисловість України. 2011. № 6(79). С. 17-18.

18. DeLuca H.F. Overview of general physiologic features and functions of vitamin D [Текст]. American Journal of Clinical Nutrition. Vol. 80(6). P. 1689-1696.

19. Vitamin D and bone [Текст] / Suda T, Ueno Y, Fujii K. et al. J Cell Biochem. 2002. Vol. 88. P. 259-266.

20. Underwood J.L., DeLuca H.F. Vitamin D is not directly necessary for bone growth and mineralization [Текст]. Am J Physiol. 1984. Vol. 246. P. 493- 498.

21. Бортнічук О.В., Гавриш А.В., Нєміріч О.В., Доценко В.Ф. Інноваційні підходи в технології хлібобулочних виробів з сухою молочною сироваткою. Харчова наука $i$ технологія. 2015. № 2(31). С. 97-102.

22. Бортнічук О.В. Удосконалення технології хлібобулочних виробів геродієтичного призначення: Дис. ...канд. тех. наук: 05.18.16. Київ, 2018. 152 с.

23. Роте М., Еникеевой Н.Г., Вейцель Э.Я. Аромат хлеба / под ред. Л.Я. Ауэрмана. Москва: Пищ. пром-сть, 1988. 230 с.

24. Технохімічний контроль сировини та хлібобулочних і макаронних виробів : навчальний посібник [Текст] / за ред. чл.-кор. В.І. Дробот. Київ: НУХТ, 2015.902 с. 